\title{
WORKS CONSULTED AND CITED
}

Abdy, Jane, and Gere, Charlotte, The Souls (Sidgwick and Jackson, 1984)

Alexander, Michael, The True Blue: The Life and Adventures of Col. Fred Burnaby 184285 (Rupert Hart-Davis, 1957)

Alford, Henry S.L., and Sword, W. Dennistoun, The Egyptian Soudan: its Loss and Recovery (Macmillan, 1898)

Andrew, Christopher, Secret Service: The Making of the British Intelligence Community (Heinemann, 1985)

Annuals, 1914 illustrated, the Book of the Year (one of a series annually from 1909) (London and Manchester: Daily News and Leader, Headley Bros, n.d.)

Anon., Life of General Gordon (Walter Scott, London, 1885)

Anon., The Pictorial History of the British Empire, Social Descriptive and Biographical (London: Thomas Mitchell, PSA Book Saloon, n.d.)

Baden-Powell, Robert The Downfall of Prempeh (Methuen, 1896)

Baden-Powell, Robert Scouting for Boys: A Handbook for Instruction in Good Citizenship (C. Arthur Pearson, 34th edn 1963 [1st edn 1908])

Beckett, Ian, The Nation in Arms, 1914-1918. See Beckett and Simpson (eds), A Nation in Arms

Beckett, Ian, The Territorial Force. See Beckett and Simpson (eds), A Nation in Arms Beckett, Ian, and Simpson, Keith (eds), A Nation in Arms: A Social Study of the British Army in the First World War (Manchester University Press, 1985)

Beresford, Lord Charles, and Wilson, H.W., Ironclads in Action (Harmsworth Bros, n.d.)

Bethell, Lieut-Col. L.A. (ed), 'Blackwood', Tales from the Outposts, II, Small Wars of the Empire (Blackwood, 1932)

Bethell, Lieut-Col. L.A. (ed), 'Blackwood', Tales from the Outposts, VII, Soldiers' Tales (Blackwood, 1933)

Blake, J.P. (ed), Official Regulations for the Volunteer Training Corps (W.H. Smith, Wymans, 1915)

Blatchford, Robert, The War that was Foretold (New and Revised ed August 1914) (Reprinted from The Daily Mail 13-23 December, 1909)

Bombardier ' $\mathrm{X}$ ', So this was War! (Hutchinson, 1930)

Bond, Brian, The Victorian Army and the Staff College 1853-1914 (Eyre Methuen, 1972) Boyle, Andrew, The Riddle of Erskine Childers (Hutchinson, 1977)

Brooke, Rupert, The Collected Poems of Rupert Brooke, with a Memoir (Sidgwick and Jackson, 1918)

Buchan, John, The Thirty-Nine Steps (1915), Greenmantle (1916), Mr Standfast (1919)

Burnaby, Captain F., A Ride to Khiva (Cassel Petter and Galpin, 2nd edn 1876)

Butler, Sir William, Charles George Gordon (Macmillan, 1903) (1st edn 1889, 10th reprint) Cassell's History of the Boer War 1899-1902 (Cassell and Co. Ltd, 2 vols, n.d.)

Cattermole, M.J., and Wolfe, A.F., Horace Darwin's Shop: a History of Cambridge Scientific Instrument Company 1878-1968 (Adam Hilager, 1987)

Chamberlain, Joseph, Patriotism. An address delivered to the Students of the University of Glasgow ...on November 3rd, 1897, on the occasion of his installation as Lord Rector, (Constable, 1897)

Childers, R. Erskine, In the Ranks of the CIV (Smith, Elder and Co, 1900)

Childers, R. Erskine, The Riddle of the Sands: A Record of Secret Service, 26th 


\section{WORKS CONSULTED AND CITED}

impression (Sidgwick and Jackson, 1949 [1st edn Smith, Elder, and Co, May 1903])

Churchill, Randolph, Lord Derby - 'King of Lancashire' (Heinemann, 1959)

Churchill, Lieut-Col. Seton, General Gordon, a Christian Hero (Nisbet, n.d.)

Churchill, W.S., My Early Life (Macmillan, 1931), The World Crisis 1911-1918 new edn, 2 vols (Odhams, 1938), Young Winston's Wars (ed. Frederick Woods) (Leo Cooper, 1972)

Clarke, I.F., Voices Prophesying War (Oxford University Press, 1966)

Clarke, J. Erskine, Going for a Soldier and Other Tales (Wells, Gardner, Darton and Co, 1899)

Clausewitz, Carl von, On War, 3 vols translated by Col. J.J. Graham (Trübner, 1873), new and revised edn, 3 vols with Introduction and notes by Col. F. N. Maude (Kegan Paul, Trench, Trübner, 1908)

\section{Collections}

Peril and Patriotism: True Tales of Heroic Deeds and Startling Adventures, Introduction by H.O. Arnold-Foster, MP (Cassell, 1901)

At Duty's Call Stories by Gordon Stables, Harold Bindloss, A.E. Johnson, C.E. Gouldsburg, Duncan McLaren, Frank Savile, S.A. Parkes, F.S. Bowley (John F. Shaw, n.d. [c.1905])

Our Soldiers and Sailors: The Empire's Defenders in War and Peace, with 22 coloured plates and 600 illustrations (Ward, Lock, n.d. [pre-1914])

The Wonder Book of Empire (Ward, Lock, n.d. [pre-1914 text probably published during the Great War])

Cooper, A. Duff, Old Men Forget (Rupert Hart-Davis, 1953)

Cousins, Geoffrey, The Defenders: A History of the British Volunteer (Frederick Muller, 1968)

Crozier, Brig-Gen. F.P., The Men I Killed (Michael Joseph, 1937)

Cunningham, Hugh, The Volunteer Force (Croom Helm, 1975)

Darracott, Joseph and Loftus, Belinda, First World War Posters (Imperial War Museum, 1972)

Dawson, A.J., How to help Lord Kitchener (Hodder and Stoughton, 1914)

Dawson, John, Practical Journalism, how to enter thereon and succeed (L. Upcott Gill, Strand, n.d.)

Dilke, Sir Charles, Greater Britain - A record of Travel in English-speaking countries during 1866 and 18672 vols (Macmillan, 1868)

Dilke, Sir Charles, The British Army (Chapman and Hall, 1888)

Diver, Maud, Captain Desmond VC (Edinburgh and London: Blackwood, 1908); The Hero of Herat (Edinburgh and London: Blackwood, 1912); Desmond's Daughter (Edinburgh and London: Blackwood, 1916)

Doyle, A. Conan The Great Boer War (Smith, Elder, 4th Impression 1900)

Dunlop, John K., The Development of the British Army 1899-1914 (Methuen, 1938)

Eden, Anthony, Another World 1897-1917 (Allen Lane, 1976)

Edmonds, Charles, A Subaltern's War (Peter Davies, 1929)

Emery, Frank, The Red Soldier: Letters from the Zulu War, 1879 (Hodder and Stoughton, 1977)

Escott, T.H.S., England: its People, Polity and Pursuits 2 vols (Cassell, Petter, Galpin and Co, n.d.)

Farwell, Byron E., The Great Boer War (Allen Lane, 1977)

Fenn, G. Manville, George Alfred Henty: The Story of an Active Life (Blackie, 1907) 


\section{AT DUTY'S CALL}

Fitchett, W.H., Fights for the Flag, 2nd impression (Smith, Elder, 1898); Deeds that won the Empire, 12th edn (Smith, Elder, 1900)

Fletcher, C.R.L. and Kipling, R., A History of England, new edn, revised and coloured (Oxford: Clarendon Press; London; Hodder and Stoughton, 1911)

Forbes, Archibald, Barracks, Bivouacs and Battles (Macmillan, 1892)

Forbes-Mitchell, William, Reminiscences of the Great Mutiny 1857-59 (Macmillan, 1895)

Fuller, Major-General J.F.C., The Last of the Gentlemen's Wars (Faber and Faber, 1937)

Girouard, Mark, The Return to Camelot - Chivalry and the English Gentleman (Yale University Press, 1981)

Gooch, John, The Prospect of War (Cass, 1981)

Grainger, J.H., Patriotisms: Britain 1900-1939 (Routledge and Kegan Paul, 1986) Great Public Schools (Arnold, n.d.)

Hale, M.H., Volunteer Soldiers 2nd edn (Kegan Paul, Trench, Trübner, 1900)

Hamley, Sir Edward, National Defence - Articles and Speeches (Blackwood, 1889)

Hankey, Donald, A Student in Arms (Andrew Melrose, 1917)

Haste, Cate, Keep the Home Fires Burning (Allen Lane, 1978)

Hay, Ian, The First Hundred Thousand (Blackwood, 1916)

Henley, W.E. Lyra Heroica, a Book of Verse for Boys (Macmillan, 1921 [1st edn 1891]); Poems (David Nutt, London, 1898)

Hillcourt, William, Baden-Powell, The Two Lives of a Hero (with Olave, Lady BadenPowell) (Heinemann, 1964)

Hislam, Percival A., The Admiralty of the Atlantic: An Enquiry into the Development of German Sea Power Past, Present and Prospective (Longmans, Green, 1908)

HMSO Statistics of the Military Effort of the British Empire 1914-1920 (HMSO, 1922)

Honey, J.R. de S. Tom Brown's Universe (Millington, 1977)

Hough, Richard, First Sea Lord: An Authorized Biography of Lord Fisher (Allen and Unwin, 1969)

Howarth, Patrick, Play Up and Play the Game (Eyre Methuen, 1973)

Hughes, Clive, 'The New Armies'. See Beckett and Simpson (eds), A Nation in Arms

Inglis, The Hon. Lady, The Siege of Lucknow (James R. Osgood, Mcllvaine and Co, 1893)

Innes, A.D., A History of the British Nation (T.C. and E.C. Jack, 1912)

Kennedy, Paul M., The Rise of the Anolo-German Antagonism 1860-1914 (George Allen and Unwin, 1980-82)

Kernahan, Coulson, The Experiences of a Recruiting Officer (Hodder and Stoughton, 1915)

Kingston, W.H.G., Our Sailors: Anecdotes of the Engagements and Gallant Deeds of the British Navy during the Reign of Her Majesty Queen Victoria, new edn, Griffith Farran \& Co, n.d.); How Britannia came to Rule the Waves (Gall and Inglis, n.d. [not before 1876])

Kipling, Rudyard, Plain Tales from the Hills, Soldiers Three, Wee Willie Winkie, Life's Handicap, Many Inventions, The Day's Work, Stalky and Co, The Five Nations, Traffics and Discoveries, Puck of Pook's Hill, Rewards and Fairies, A Diversity of Creatures, Debits and Credits, Kim, The Seven Seas; also The Jungle Book, The Second Jungle Book, The Just-So Stories (Macmillan, various dates and editions, 1888-1926)

MacKenzie, Jeanne, The Children of the Souls (Chatto and Windus, 1986)

MacKenzie, John M., Propaganda and Empire (Manchester University Press, 1984)

Maclean, A.H.H., Public Schools and the War in South Africa (Edward Stanford, 1903)

Magnus, Philip, Kitchener - Portrait of an Imperialist (John Murray, 1958) 


\section{WORKS CONSULTED AND CITED}

Mangan, J.A., Athleticism in the Victorian and Edwardian Public School (Cambridge University Press, 1981)

Marsh, Sir Edward, Memoir of Rupert Brooke. See The Collected Poems of Rupert Brooke

Marshall, H.E., Our Empire Story (T.C. and E.C. Jack, n.d. [1908]); Our Island Story (Nelson, n.d.)

Mason, Philip, A Matter of Honour. An account of the Indian Army, its officers and men (Cape, 1974)

Mason, Philip, Kipling: The Glass, the Shadow and the Fire (Cape, 1975)

Morris, A.J.A., The Scaremongers: The Advocacy of War and Rearmament 1896-1914 (Routledge and Kegan Paul, 1984)

Munro, H.H. ('Saki'), When William Came (John Lane, The Bodley Head, 1914)

Newbolt, Sir Henry, The Old Country (Smith, Elder, 1906); Clifton Chapel and other School Poems (John Murray, 1909); Poems: New and Old (John Murray, 1912); The Book of the Happy Warrior (Longman, 1917); My World as in my Time (Faber and Faber, 1932)

Owen, Wilfred, The Poems of Wilfred Owen, ed. with a memoir and notes by Edmund Blunden (Chatto and Windus, 1933)

Palmer, A.W., A Dictionary of Modern History 1789-1945 (Cresset Press, 1962)

Parker, Peter, The Old Lie: The Great War and the Public School Ethos (Constable, 1987)

\section{Parliamentary papers}

Report of the Commissioners appointed to inquire into the Condition of the Volunteer Force in Great Britain (HMSO, 1862)

Report of the Public Schools Commission (BPP. 1864), $\mathrm{xx}$

Correspondence respecting the Offers by the Colonies of Troops for Service in the Soudan, C4437/1885 (in continuation of C4324 of March 1885)

Report of H.M. Commissioners [on] ... the War in South Africa, Cd 1789/1903

\section{Periodicals}

The Boy's Own Paper

The Daily Express

The Daily Mail

Illustrated War News

John Bull

Journal of Modern History 42 (March-December, 1970), pp. 564-85, Roy Douglas,

'Voluntary enlistment in the First World War and the work of the Parliamentary Recruiting Committee'.

\section{The nineteenth century and after}

\section{Punch}

The Times, The Times Recruiting Supplement 3, November 1915

Pimblett, W., How the British Won India (J.S. Virtue, 1895)

Plumb, J.H. (ed), Studies in Social History (Longman, 1955)

Pound, Reginald, The Lost Generation (Constable, 1964)

Price, Richard, An Imperial War and the British Working Class (Routledge and Kegan

Paul, and University of Toronto Press, 1972)

Punch, Mr Punch's History of the Great War (Cassell, 1920) 


\section{AT DUTY'S CALL}

Richards, Frank, Old Soldier Sahib (Faber and Faber, 1936)

'Richards, Frank', The Autobiography of Frank Richards (Charles Skilton, 1952)

Roberts of Kandahar, Lord, Forty-one Years in India, from Subaltern to Commander-inChief 5th edn, 2 vols (Richard Bentley, 1897)

Robertson, J.M., Patriotism and Empire (Grant Richards, 1899)

Robson, L.L., The First AIF (Melbourne University Press, 1970)

Ryder, Rowland, Edith Cavell (Hamish Hamilton, 1975)

Simpson, Keith, 'The Officers'. See Beckett and Simpson (eds), A Nation in Arms

Smith, G. Barnett, General Gordon: The Christian Soldier and Hero (Partridge, n.d.)

Smith, R. Bosworth, Life of Lord Lawrence, 3rd edn, 2 vols (Smith, Elder, 1883)

Spiers, Edward M., 'The Regular Army in 1914'. See Beckett and Simpson (eds), A Nation in Arms

Stables, Gordon, MD, RN, By Sea and Land: A Tale of the Blue and Scarlet (Frederick Warne, n.d. [1898?])

Stanley, Arthur Penrhyn, The Life and Correspondence of Thomas Arnold DD, 13th edn, 2 vols (John Murray, 1882)

Steel, Flora Annie, The Potter's Thumb (1894); On the Face of the Waters (1896)

Steevens, G.W., With Kitchener to Khartum, 11th edn (Blackwood, 1898); In India (Blackwood, 1899); Things Seen, with a Memoir by W.E. Henley (Blackwood, 1900)

Steinberg, Jonathan, Yesterday's Deterrent: Tirpitz and the Birth of the German Battle Fleet (Macdonald, 1965)

Stewart, A.T.Q., The Ulster Crisis (Faber and Faber, 1967)

Stone, Christopher (ed.), War Songs, selected by Christopher Stone with an Introduction by General Sir Ian Hamilton (Clarendon, 1908)

Simon, Brian and Bradley, Ian (eds), The Victorian Public School (Gill and Macmillan, 1975)

The Times Diary and History of the War (The Times Publishing Co Ltd, n.d.)

The Times History of the War, I (n.d.); V (1915); VI (1916)

Trollope, Joanna, Britannia's Daughters (Hutchinson, 1983)

Trotter, Captain Lionel J., Life of John Nicholson, 6th edn (John Murray, 1898); The Bayard of India: A Life of General Sir James Outram, Everyman Edn (Dent, 1909, [1st edn 1903])

Tuchman, Barbara, The Proud Tower (Hamish Hamilton, 1966)

Usborne, Richard, Clubland Heroes, revised edn (Barrie and Jenkins, 1974)

Warner, Philip, The Best of British Pluck (Macdonald and Jane's 1976)

Weber, Eugen, Peasants into Frenchmen: The Modernization of Rural France 1870-1914 (Chatto and Windus, 1977)

War Office, Textbook of Small Arms (HMSO, 1929)

Williams, Basil, Raising and Training the New Armies (Constable, 1918)

Wilson, H.W., and Hammerton, J.A., The Great War, vol 5 (Amalgamated Press, 1916)

Winter, Jay, 'Army and Society: the demographic context'. See Beckett and Simpson (eds), A Nation in Arms Winter, Jay, The Great War and the British People (Macmillan, 1985)

Wolseley, Field-Marshal, Viscount, The Story of a Soldier's Life, 2 vols (Constable, 1903)

Wood, Sir Evelyn, From Midshipman to Field-Marshal, 5th edn (Methuen, 1907 [1st edn, October, 1906])

Woods, Frederick (ed.), Young Winston's Wars: The Original Despatches of Winston S. Churchill, War Correspondent 1897-1900 (Lto Cooper Ltd, 1972)

Younghusband, Major General Sir George, The Story of the Guides (Macmillan, 1909); A Soldier's Memories in Peace and War (Herbert Jenkins, 1917) 